\title{
Lithium in Greenland ice cores measured by ion chromatography
}

\author{
Marie-Louise SigGaARD-ANDERsen, ${ }^{1}$ Jørgen Peder STefFensen, ${ }^{2}$ Hubertus FiSGHER ${ }^{1}$ \\ ${ }^{1}$ Alfred Wegener Institute for Polar and Marine Research, Columbusstrasse, P.O. Box 120161, D-27515 Bremerhaven, Germany \\ E-mail: mlsiggaard@awi-bremerhaven.de \\ ${ }^{2}$ Department of Geophysics, Niels Bohr Institute for Astronomy, Physics and Geophysics, Fuliane Maries Vej 30, DK-2100 Copenhagen, Denmark
}

\begin{abstract}
Ion chromatography (IC) is a widely used technique for analyzing ice cores for ions like $\mathrm{Na}^{+}, \mathrm{NH}_{4}{ }^{+}, \mathrm{K}^{+}, \mathrm{Mg}^{2+}, \mathrm{Ca}^{2+}, \mathrm{F}^{-}, \mathrm{MSA}^{-}, \mathrm{Cl}^{-}, \mathrm{NO}_{2}^{-}$and $\mathrm{SO}_{4}{ }^{2-}$ that are present in polar ice cores at ppb level. By using sample preconcentration and an optimized separation technique, we have been able to detect $\mathrm{Li}^{+}$in ice-core samples in concentrations as low as $0.0001 \mu \mathrm{eq} \mathrm{kg}^{-1}$ or $0.7 \mathrm{ppt}$ by IC. During routine analysis of ions in ice cores, the lithium content has been evaluated and recorded. The IC technique used in these measurements and some exemplary IC data from the Greenland Icecore Project (GRIP) and the North Greenland Icecore Project (NorthGRIP) ice cores are presented. By these data we introduce $\mathrm{Li}^{+}$concentration as a new parameter in the analysis of ice cores. Like other ions, $\mathrm{Li}^{+}$reflects climatic changes and shows seasonal cycles. On the basis of the geochemistry of lithium, we suggest that $\mathrm{Li}^{+}$measured in the Greenland ice cores is derived from mineral dust. However, data from the NorthGRIP ice core representing the $8.2 \mathrm{kyr}$ BP Holocene cold event show a strong $\mathrm{Li}^{+}$signal that does not correlate with any other ionic component measured. This means that the lithium content in ice cores is a signal with its own pattern, which is not yet understood.
\end{abstract}

\section{INTRODUGTION}

Ion chromatography (IC) is a convenient and reliable method widely used to analyze soluble chemical components like $\mathrm{Na}^{+}, \mathrm{NH}_{4}^{+}, \mathrm{K}^{+}, \mathrm{Mg}^{2+}, \mathrm{Ca}^{2+}, \mathrm{F}^{-}, \mathrm{MSA}^{-}, \mathrm{Cl}^{-}$, $\mathrm{NO}_{3}{ }^{-}$and $\mathrm{SO}_{4}{ }^{2-}$ in ice cores where these ions are present at the ppb level (e.g. Mayewski and others, 1997). Two of the main contributors to the Greenland ice-core ion chemistry are sea salts and ions released from mineral dust particles. The $\mathrm{Na}^{+}$concentration is often taken as an indicator for the content of sea-salt aerosols. Non-sea-salt contributions to the contents of various ionic components in ice cores can be evaluated by subtraction of the sea-salt contribution (e.g. De Angelis and others, 1997). The content in Greenland ice cores of soluble $\mathrm{Ca}^{2+}$ correlates well with the content of insoluble dust (Steffensen, 1997), and use of the $\mathrm{Ca}^{2+}$ concentration as an indicator for the content of dust aerosols is well established (e.g. Fuhrer and others, 1999). The insoluble mineral-dust aerosols are mostly aluminium silicates (e.g. Laj and others, 1997; Svensson and others, 2000). Iron and aluminium are therefore better tracers for insoluble dust aerosols than $\mathrm{Ca}^{2+}$, but the number of data from analysis of these elements in ice cores is limited due to the tedious analytical technique. Contributions to ions in Greenland ice cores other than sea salt and mineral dust aerosols can be aerosols of biogenic or volcanic origin.

Very little has been reported about IC measurements of lithium in geological samples, because up to now the IC technique has been insufficient. IC methods for measuring $\mathrm{Li}^{+}$were optimized by Betti and others (1991), who measured $\mathrm{Li}^{+}$along with other cations using column switching, and by Singh and Abbas (1996), who measured only mono- valent alkali metals. After sample dilution they measured $\mathrm{Li}^{+}$in concentrations down to $0.5 \mu \mathrm{eq} \mathrm{kg}^{-1}$. But since their work, IC techniques have improved markedly. Today all components of interest are easily separated in a single run, and the procedures for measurement and data evaluation have become automated to a high degree. Lyons and Welch (1997) measured $\mathrm{Li}^{+}$concentrations in stream and lake samples during IC analysis of chemistry in waters from the McMurdo Dry Valleys, Antarctica. They report a detection limit of $0.01 \mu \mathrm{eq} \mathrm{kg}^{-1}$, and after sample dilution they measured $\mathrm{Li}^{+}$concentrations down to about $0.1 \mu \mathrm{eq} \mathrm{kg}{ }^{-1}$. In this work, we present an IC method where $\mathrm{Li}^{+}$concentrations down to $0.0001 \mu \mathrm{eq} \mathrm{kg}{ }^{-1}$ or $0.7 \mathrm{ppt}$ can be measured, and we introduce the $\mathrm{Li}^{+}$concentration as a new parameter in the analysis of ice cores.

Since sea salt and mineral dust aerosols are two of the main contributors to ion chemistry in Greenland ice cores,

Table 1. The average lithium and relative lithium abundance in the upper crust and sea water, from Holland (1984) and Wedepohl (1995). The ratios are given in equivalents/equivalents

\begin{tabular}{lcc}
\hline & Uppercrust & Seawater \\
\hline Lithium (ppmw) & 22 & 0.19 \\
$\mathrm{Li} / \mathrm{Ca}($ eq/eq) & 0.0022 & 0.0014 \\
$\mathrm{Li} / \mathrm{Na}$ & 0.0028 & $0.061 \times 10^{-3}$ \\
$\mathrm{Li} / \mathrm{Mg}$ & 0.0029 & $0.27 \times 10^{-3}$ \\
$\mathrm{Na} / \mathrm{Ca}$ & 0.76 & 23 \\
$\mathrm{Mg} / \mathrm{Na}$ & 1.0 & 0.22 \\
$\mathrm{Mg} / \mathrm{Ca}$ & 0.76 & 5.1 \\
\hline
\end{tabular}


we consider the contribution of these two sources to the $\mathrm{Li}^{+}$ content in our samples. In Table 1 the abundance of lithium relative to other elements in the Earth upper crust and in sea water is listed. In sea water, the molar ratio between lithium and sodium is $0.061 \times 10^{-3}$ (Holland, 1984), which is much lower than the ratios we have measured. We therefore assume that the origin of lithium in Greenland ice cores is mainly mineral dust aerosols. This assumption is supported by recent analysis of single-particle aerosol using aerosol time-of-flight mass spectrometry in air masses in Southern California., U.S.A. There Silva and others (2000) detected lithium in soil dust particles, and Hughes and others (2000) used lithium, along with aluminium, iron and calcium, as an indicator for mineral dust particles in the analysis of the evolution of various atmospheric particles. In the Earth's upper crust, the lithium and calcium contents are 22 and 29450 ppm (Wedepohl, 1995), corresponding to $3.1 \mathrm{meq} \mathrm{kg}^{-1}$ and $1.47 \mathrm{eq} \mathrm{kg}^{-1}$, respectively. Lithium has a very low solubility in water, but a very high mobility during chemical weathering processes, and replaces magnesium in rocks and minerals (Heier and Billings, 1970). The lithium content in minerals varies (see Table 2), and the concentration of lithium in clays and sedimentary rocks is much higher than in igneous rocks and fresh basalts. In fresh basalts, the lithium content is typically $5 \mathrm{ppm}$, whereas in some clays it can be $150 \mathrm{ppm}$ (Holland, 1984). Lithium is unlikely to be replacing calcium in minerals, and in marine carbonates the lithium content is very low (Hoefs and Sywall, 1997). Because of this variation in lithium content in minerals, the relative concentrations of $\mathrm{Li}^{+}, \mathrm{Mg}^{+}$and $\mathrm{Ca}^{2+}$ measured in Greenland ice cores might be useful in the study of mineral composition of dust aerosols.

Here we present exemplary $\mathrm{Li}^{+}$profiles along with $\mathrm{Ca}^{2+}$ profiles from three different data series. One series represents 70 years around 400 years BP from the North Greenland Icecore Project (NorthGRIP) Holocene ice core (personal communication from H. B. Clausen, 2001) where a seasonal signal in the $\mathrm{Li}^{+}$profile can be seen and where $\mathrm{Li}^{+}$was measured in concentrations as low as $0.0001 \mu \mathrm{eq} \mathrm{kg}{ }^{-1}$ or $0.7 \mathrm{ppt}$. Another series represents the Greenland Icecore Project (GRIP) icecore Greenland Stadial 21 (GS-21) to Greenland Interstadial 20 (GIS-20) transition approximately 75 kyr BP (Dansgaard and others, 1993; Walker and others, 1999). The third series we have chosen to present is from the NorthGRIP ice core representing approximately 170 years around the Holocene $8.2 \mathrm{kyr}$ BP cold event (personal communication from H.B. Clausen, 2001). The $8.2 \mathrm{kyr} B \mathrm{P}$ event has been described by, among others, Klitgaard-Kristensen and others (1998) and has been analyzed in the Greenland Ice Sheet Project 2 (GISP2) ice core by Alley and others (1997). In the NorthGRIP ice-core series the lithium profile shows a strange and incomprehensible behaviour during this event.

\section{ICE-GORE SAMPLES}

The GRIP ice core was drilled during the 1990, 1991 and 1992 summer field seasons and reached $3028 \mathrm{~m}$ depth very close to bedrock (Dansgaard and others, 1993). The NorthGRIP 1 ice core was drilled during the 1996 and 1997 summer field seasons and terminated at $1371 \mathrm{~m}$ depth (DahlJensen and others, 2002).

Samples for IC analysis were decontaminated and cut into 5.0 or $2.5 \mathrm{~cm}$ samples manually in a clean bench using a microtome knife and then stored frozen in Coulter accuvettes. Except for a few samples from the GRIP ice core, all the samples have been decontaminated and cut in the field.

From the NorthGRIP 1 ice core, the upper $350 \mathrm{~m}$ were sampled for a continuous record in $5 \mathrm{~cm}$ resolution, and below $350 \mathrm{~m}$ depth selected sections were sampled.

\section{IC METHOD}

The ions in the ice-core samples were measured using a DIONEX 500 microbore ion chromatograph equipped with a two-channel set-up for simultaneous measurements of cations and anions. Each channel has a preconcentration column, gradient pump, suppressor and a conductivity detector. The samples were decanted into $5 \mathrm{~mL}$ sample vials and injected into the ion chromatograph by an autosampler. From each sample a $3 \mathrm{~mL}$ portion was injected into the cation system, and a $1.5 \mathrm{~mL}$ portion was injected into the anion system. The ionic components were separated within $20 \mathrm{~min}$ for both cations and anions.

The cations were separated on Ionpac CS12 $2 \mathrm{~mm}$ columns using a gradient mixture of 20 meq kg ${ }^{-1}$ methanesulphonic acid (MSA) and $18 \mathrm{M} \Omega$ water as eluent with a flow rate of $0.5 \mathrm{~mL} \mathrm{~min}^{-1}$. The initial eluent concentration was $9 \mathrm{meq} \mathrm{kg}^{-1} \mathrm{MSA}$ with a gradient increase up to $16 \mathrm{meq} \mathrm{kg}^{-1}$ between 2 and 12 min. Between 12 and $16 \mathrm{~min}$ the eluent concentration was constant at $16 \mathrm{meq} \mathrm{kg}^{-1}$ and then changed back to $9 \mathrm{meq} \mathrm{kg}^{-1}$ for the baseline to relax

The application of a preconcentration column decreases markedly the effect of the water dip in the beginning of the chromatograms, and therefore a large sample volume can be injected. Since lithium is present in ice-core samples in very low concentrations, a large sample volume is essential for the detection of lithium. The decreased effect of the water dip is also an advantage because $\mathrm{Li}^{+}$is the first component in the cation chromatograms. With a low initial eluent concentration the lithium peak is distant from the water dip, and a good separation of the first four components $\mathrm{Li}^{+}, \mathrm{Na}^{+}$, $\mathrm{NH}_{4}{ }^{+}, \mathrm{K}^{+}$is achieved. A high eluent flow rate ensures a low detection limit since the component peaks are easier to distinguish from baseline noise. Important for a low detection limit is a high chemical purity of the eluent and an optimally working pump and suppressor. The gradient in the eluent concentration is applied for the components $\mathrm{Mg}^{2+}$ and $\mathrm{Ca}^{2+}$ to be measured along with the monovalent cations within $20 \mathrm{~min}$. The chromatograms were integrated using Peaknet 4.30 software, and the peak heights were used in the data evaluation except when the peak area seemed to be more reproducible. In Figure 1 the detector responses of the first four components in the cation chromatograms are shown for a standard solution and for a sample solution. The $\mathrm{Li}^{+}$concentration in the standard solution is $0.2 \mu \mathrm{eq}$ $\mathrm{kg}^{-1}$, and the $\mathrm{Li}^{+}$concentration in the sample was evaluated to $0.00025 \mu \mathrm{eq} \mathrm{kg}^{-1}$.

Reproducibility and linearity of the $\mathrm{Li}^{+}$response was tested on solutions with $\mathrm{Li}^{+}$concentrations of 0.2, 0.02, 0.002 and $0.0002 \mu \mathrm{eq} \mathrm{kg}^{-1}$. The tests showed no significant deviation from linearity of the $\mathrm{Li}^{+}$response for concentrations down to $0.002 \mu \mathrm{eq} \mathrm{kg}^{-1}$. For $0.0002 \mu \mathrm{eq} \mathrm{kg}^{-1} \mathrm{Li}^{+}$the tests showed a positive deviation from linearity of $<+20 \%$. This means that, using a linear calibration curve, $\mathrm{Li}^{+}$concentrations evaluated to around $0.0002 \mu \mathrm{eq} \mathrm{kg}^{-1}$ are overestimated by $<20 \%$. The standard deviation for repeated measurements of solutions 


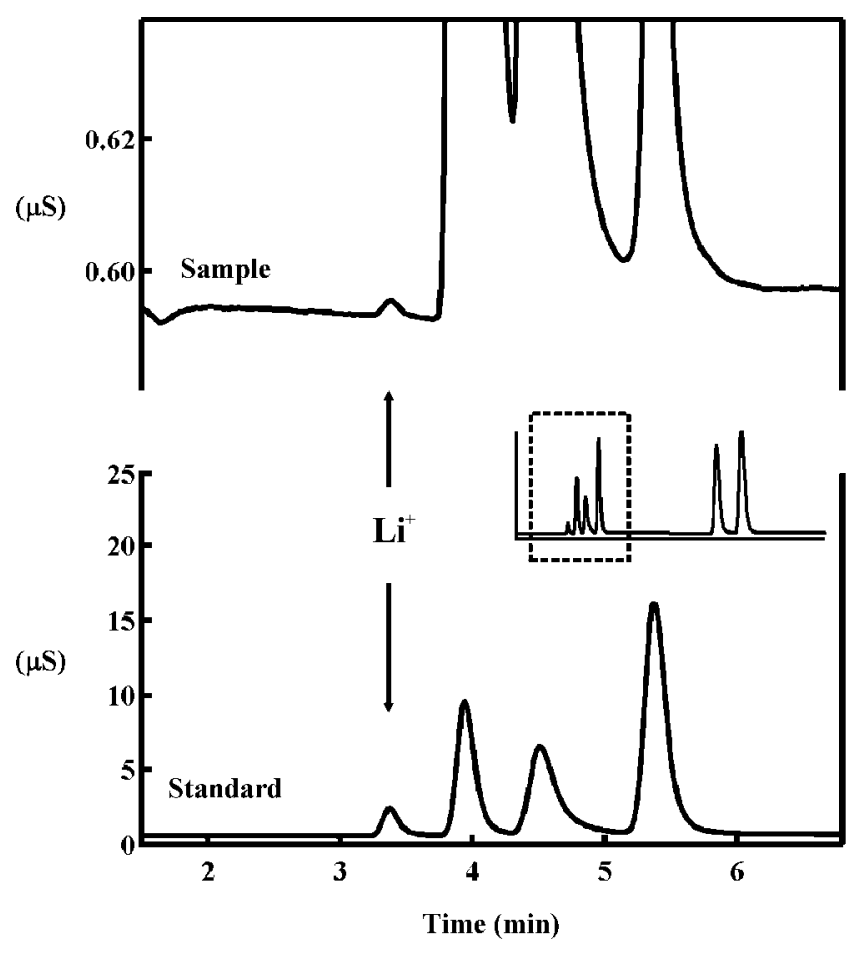

Fig. 1. The detector response vs time for the first four components in the cation chromatograms is shown for a sample solution and for a standard solution. The cations measured are $\mathrm{Li}^{+}, \mathrm{Na}^{+}$, $\mathrm{NH}_{4}^{+}, \mathrm{K}^{+}, \mathrm{Mg}^{2+}$ and $\mathrm{Ca}^{2+}$. The $\mathrm{Li}^{+}$concentration in the standard was $0.2 \mu \mathrm{eq} \mathrm{kg}^{-1}$. The sample concentration of $\mathrm{Li}^{+}$ was evaluated to $0.0003 \pm 0.0001 \mu e q \mathrm{~kg}^{-1}$.

with $\mathrm{Li}^{+}$concentrations of $0.2,0.02,0.002$ and $0.0002 \mu \mathrm{eq} \mathrm{kg}^{-1}$ was $<5 \%,<5 \%, 10 \%$ and $10-15 \%$, respectively. After standard solutions of $0.2 \mu \mathrm{eq} \mathrm{kg}^{-1} \mathrm{Li}^{+}$and $4.1 \mu \mathrm{eq} \mathrm{kg}{ }^{-1} \mathrm{Ca}^{2+}$ two blank solutions were measured. In the first blanks an average of $0.0001 \mu \mathrm{eq} \mathrm{kg}^{-1} \mathrm{Li}^{+}$was measured with a reproducibility of $17 \%$, corresponding to a carry-over of $0.07 \%$ of the previous standard solution. $\mathrm{No} \mathrm{Li}^{+}$was detected in second blanks. For $\mathrm{Ca}^{2+}$ there was a carry-over of $4 \%$ in the first blanks.

During routine IC measurements of samples from various ice cores, the $\mathrm{Li}^{+}$content was evaluated and recorded. The detection limits for components in the chromatograms depend on how well the system was running. For an optimally working system, the detection limits, taken as three times the height of baseline noise, were $0.0001 \mu \mathrm{eq} \mathrm{kg}^{-1}$ for $\mathrm{Li}^{+}$and $0.0002 \mu \mathrm{eq} \mathrm{kg}{ }^{-1}$ for $\mathrm{Ca}^{2+}$. In practice, calcium has a much higher detection limit of $0.05 \mu \mathrm{eq} \mathrm{kg}^{-1}$, which is determined by blank concentrations. During automatic data evaluation, the detection limit is controlled by parameters in the integration software, and it was possible to detect $\mathrm{Li}^{+}$peaks smaller than corresponding to $0.0001 \mu \mathrm{eq} \mathrm{kg}^{-1}$ in chromatograms of high quality. This means that $\mathrm{Li}^{+}$concentrations as low as $0.0001 \mu \mathrm{eq} \mathrm{kg}^{-1}$ or $0.7 \mathrm{ppt}$ were evaluated. During routine IC measurements the limit for automatic detection of $\mathrm{Li}^{+}$could vary between 0.0001 and $0.0003 \mu \mathrm{eq} \mathrm{kg}^{-1}$ depending on the quality of the chromatograms.

For quantification of ion concentrations, a single standard solution was used. Deviations from linearity in the detector response of very low $\mathrm{Li}^{+}$concentrations have not been taken into account in the data evaluations. Therefore $\mathrm{Li}^{+}$concentrations around $0.002 \mu \mathrm{eq} \mathrm{kg}{ }^{-1}$ have an error of $10 \%$ from reproducibility, while $\mathrm{Li}^{+}$concentrations around $0.0002 \mu \mathrm{eq} \mathrm{kg}^{-1}$ have a total error of $30-35 \%$ from reproducibility and deviations from linearity.

Contamination of samples occasionally occurs during manual sampling and shows up as spikes in the data profiles. A typical source of contamination is fingerprints, so spikes in the sodium, potassium and chloride profiles are good indicators of sample contamination. During the manual sampling of NorthGRIP samples, $4.4 \%$ of the samples were marked as possibly contaminated. The marked samples have $91 \%, 76 \%$ and $33 \%$ higher average concentrations of sodium, potassium and chloride, respectively. For lithium the average concentration in the marked samples is $30 \%$
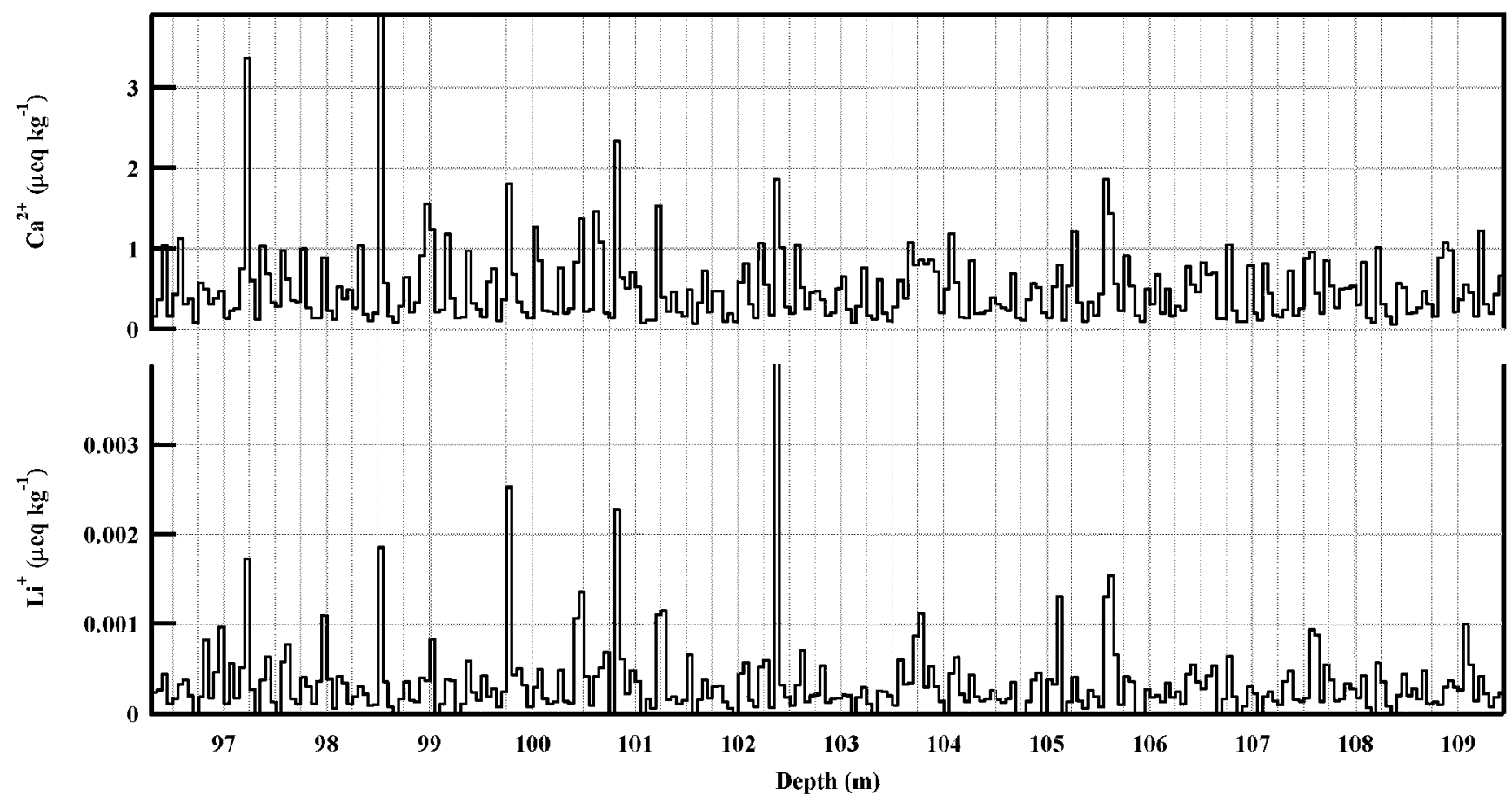

Fig. 2. NorthGRIP Holocene seasonals. $\mathrm{Ca}^{2+}$ and $\mathrm{Li}^{+}$profiles in $5 \mathrm{~cm}$ resolution from a typical Holocene section of the NorthGRIP ice core. The section represents approximately 70 years around 400 years BP. 
Table 2. Lithium content in some Quaternary ( qrt) and average (avg) sediments in ppmw, and ratios in equivalents between lithium and calcium in some Quaternary sediments. Data are evaluated from Holland (1984) and Hoefs and Sywall (1997)

\begin{tabular}{lccc}
\hline & Clay and clayshales & Sands and silts & Carbonates \\
\hline & 40 & 18 & 2 \\
$\mathrm{Li}_{\mathrm{qrt}}(\mathrm{ppmw})$ & 80 & 36 & 13 \\
$\mathrm{Li}$ avg $(\mathrm{ppmw})$ & 0.0033 & 0.0010 & 0.00002 \\
$\mathrm{Li} / \mathrm{Ca}_{\mathrm{qrt}}(\mathrm{eq} / \mathrm{eq})$ & 0.0045 & 0.0034 & 0.00013 \\
$\mathrm{Li} / \mathrm{Ca}_{\text {avg }}(\mathrm{eq} / \mathrm{eq})$ & 0.87 & 0.41 & 0.02 \\
$\mathrm{Mg} / \mathrm{Ca}_{\text {qrt }}(\mathrm{eq} / \mathrm{eq})$ & 0.64 & 0.62 & 0.27 \\
$\mathrm{Mg} / \mathrm{Ca}_{\text {avg }}(\mathrm{eq} / \mathrm{eq})$ & & & \\
\hline
\end{tabular}

higher than in unmarked samples. This shows that a few samples have been contaminated with lithium during the manual sampling. We believe that contamination during manual sampling would have affected several of the measured components and that samples contaminated with lithium are also contaminated with other components. We therefore assume that sample data that look like normal data with respect to components other than lithium represent real ice-core data with respect to lithium.

\section{PRESENTATION OF DATA}

Here we will show the $\mathrm{Li}^{+}$profiles along with the $\mathrm{Ca}^{2+}$ profiles for selected data series in order to characterize the pattern of $\mathrm{Li}^{+}$concentrations in ice cores. The complete datasets involving all the ionic components measured will be presented and discussed elsewhere.

\section{Holocene seasonals}

From the upper $350 \mathrm{~m}$ IC-data profile of the NorthGRIP ice core, $\mathrm{Li}^{+}$was measured in sample sections corresponding to approximately $250 \mathrm{~m}$. We selected a section from 96-109 m depth for this presentation. The $\mathrm{Ca}^{2+}$ and $\mathrm{Li}^{+}$profiles from the series are shown in Figure 2. This section corresponds to a time-span of approximately 70 years starting from approximately 400 years BP at $96 \mathrm{~m}$ (personal communication from H. B. Clausen, 2001). With the $5 \mathrm{~cm}$ sample resolution, seasonal variations of ionic components can be recognized in the whole $350 \mathrm{~m}$ data series, and the $\mathrm{Li}^{+}$data show seasonal variations in line with $\mathrm{Na}^{+}$and $\mathrm{Ca}^{2+}$. But the resolution of the data series is not good enough to show any details in the seasonal pattern. The average values of all the ionic components from the 96-109 m section are typical for the whole $350 \mathrm{~m}$ series. The measured $\mathrm{Li}^{+}$concentrations in this series are in the range $0.0001-0.004 \mu \mathrm{eq} \mathrm{kg}^{-1}$, with an average of $0.0003 \pm 0.0001 \mu \mathrm{eq} \mathrm{kg}^{-1}$. The ratio between the average concentrations of $\mathrm{Li}^{+}$and $\mathrm{Ca}^{2+}$ is $0.0007 \pm 0.0002$. This is comparable to ratios of lithium and calcium contents in various minerals (see Table 2).

\section{A glacial Stadial/Interstadial transition}

From the GRIP ice core a $5 \mathrm{~m}$ section at $2582.25-2587.2 \mathrm{~m}$ depth was analyzed. This section represents the transition from GS-21 to GIS-20 approximately 75 kyr BP (Dansgaard and others, 1993; Walker and others, 1999). The $\mathrm{Ca}^{2+}$ and $\mathrm{Li}^{+}$ profiles are shown in Figure 3. The data show that the $\mathrm{Li}^{+}$ concentration is higher in the cold GS-21 climate period than in the warmer GIS-20. This response to a change in climate is

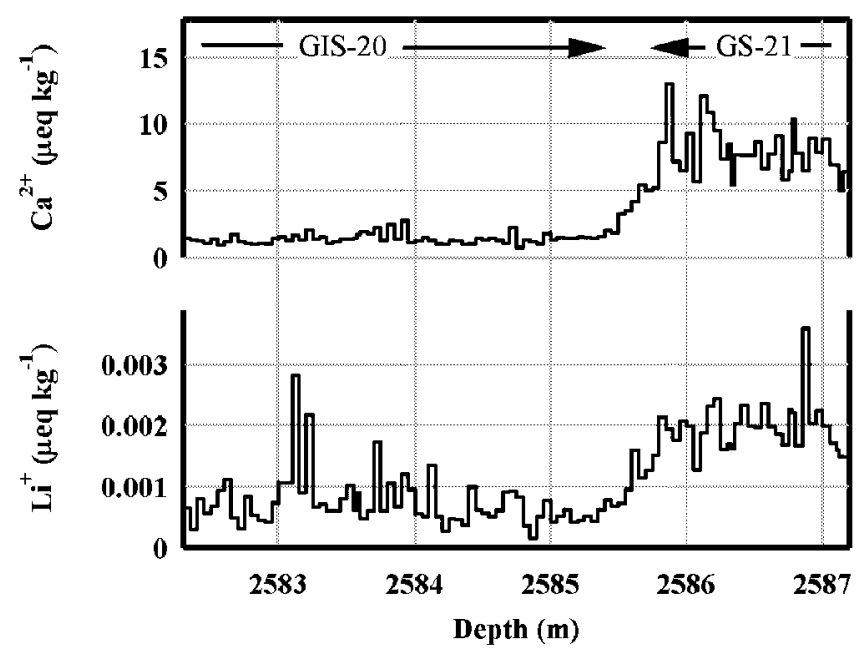

Fig. 3. $\mathrm{Ca}^{2+}$ and $\mathrm{Li}^{+}$profiles from the GRIP ice core showing the GS-21 to GIS-20 transition approximately $75 \mathrm{kyr}$ BP.

a familiar pattern seen for most ionic components measured in ice cores (e.g. Mayewski and others, 1997). Although the $\mathrm{Li}^{+}$profile looks noisy during the Interstadial the other data from this series show no sign of contamination.

The average $\mathrm{Li}^{+}$concentrations and ratios between average concentrations of cations for the three climatic periods represented by the Holocene and the glacial transition data series are listed in Table 3. To compare the values of the different climatic periods, the errors are estimated on the basis of data reproducibility. In Table 3 the ratio between $\mathrm{Li}^{+}$and $\mathrm{Ca}^{2+}$ varies with the highest value for the Holocene series and the lowest value for the GS-21 series, whereas the ratio between $\mathrm{nss} \mathrm{Mg}^{2+}$ (non-sea-salt $\mathrm{Mg}^{2+}$ ) and $\mathrm{Ca}^{2+}$ seems to be constant for the three climate series. The ratio between $\mathrm{Li}^{+}$and $\mathrm{Na}^{+}$also seems to be constant.

\section{Holocene 8.2 kyr BP cold event}

Another NorthGRIP data profile to be presented here is from a $16.5 \mathrm{~m}$ series from $1221-1237.5 \mathrm{~m}$ depth. The series represents approximately 170 years during the Holocene 8.2 kyr BP cold event (personal communication from H. B. Clausen, 2001). This series is particularly interesting with respect to the $\mathrm{Li}^{+}$ signal because the lithium content increases more than one order of magnitude, and the lithium signal does not seem to correlate with any other of the ionic components measured.

In Figure 4 the $\delta^{18} \mathrm{O}$ profile from NorthGRIP (personal communication from S. J. Johnson, 2001) is shown together with the $\mathrm{Ca}^{2+}$ and $\mathrm{Li}^{+}$profiles of this series. In the $\delta^{18} \mathrm{O}$ profile the $8.2 \mathrm{kyr}$ BP event begins at approximately $1234.5 \mathrm{~m}$ depth and ends at approximately $1219.5 \mathrm{~m}$. $\mathrm{Ca}^{2+}$ concentrations increase slowly with time at the beginning of this depth interval and seem to decrease again later during the event. $\mathrm{Li}^{+}$concentrations start to increase with time more suddenly at approximately $1232 \mathrm{~m}$ depth, which is later than the beginning of the event in the $\delta^{18} \mathrm{O}$ profile. The $\mathrm{Li}^{+}$ profile continues to increase through the whole data series and reaches values at the end that are almost two orders of magnitude higher than the values from the deepest part of the core section. This pattern of the $\mathrm{Li}^{+}$profile is not correlated to any other of the measured ionic components. Unfortunately, our $\mathrm{Ca}^{2+}$ and $\mathrm{Li}^{+}$profiles do not cover the complete cold event, so we do not know how the data profiles of $\mathrm{Li}^{+}$and $\mathrm{Ca}^{2+}$ will respond to the end of the event at approximately 
Table 3. Average values of $\delta^{18} \mathrm{O}$, average concentrations in $\mu e q \mathrm{~kg}^{-1}$ of $\mathrm{Ca}^{2+}$ and $\mathrm{Li}^{+}$and ratios between average concentrations of various cations evaluated for three different climate series: a Holocene section of the NorthGRIP ice core, and two sections from the GRIP ice core representing the GIS-20 and the GS-21 climate series

\begin{tabular}{lccc}
\hline & & Climate series & \\
& Holocene & GIS-20 & GS-21 \\
& & Section & \\
& NorthGRIP: & GRIP: & GRIP: \\
& $96.3-109.45 m$ & $2582.3-2585.3 m$ & $2585.7-25872 m$ \\
& & & \\
\hline$\delta^{18} \mathrm{O}(\%)$ & -35.47 & -36.73 & -41.58 \\
$\mathrm{Ca}^{2+}\left(\mu \mathrm{eq} \mathrm{kg}{ }^{-1}\right)$ & $0.51 \pm 0.03$ & $1.41 \pm 0.08$ & $7.8 \pm 0.4$ \\
$\mathrm{Li}{ }^{+}\left(\mu \mathrm{eq} \mathrm{kg}{ }^{-1}\right)$ & $0.0003 \pm 0.0001$ & $0.0008 \pm 0.0001$ & $0.0019 \pm 0.0002$ \\
$\mathrm{Li} / \mathrm{Na}(\mathrm{eq} / \mathrm{eq})$ & $0.0010 \pm 0.0002$ & $0.0013 \pm 0.0002$ & $0.0011 \pm 0.0002$ \\
$\mathrm{Li} / \mathrm{Ca}$ & $0.00066 \pm 0.00014$ & $0.00053 \pm 0.00008$ & $0.00025 \pm 0.00004$ \\
$\mathrm{Li} / \mathrm{Mg}$ & $0.0019 \pm 0.0004$ & $0.0016 \pm 0.0003$ & $0.0010 \pm 0.0001$ \\
$\mathrm{Li} / \mathrm{nssMg} \mathrm{Mg}$ & $0.0034 \pm 0.0007$ & $0.0022 \pm 0.0004$ & $0.0012 \pm 0.0002$ \\
$\mathrm{Na} / \mathrm{Ca}$ & $0.65 \pm 0.07$ & $0.41 \pm 0.04$ & $0.22 \pm 0.02$ \\
$\mathrm{Mg} / \mathrm{Ca}$ & $0.36 \pm 0.04$ & $0.33 \pm 0.03$ & $0.26 \pm 0.03$ \\
$\mathrm{nssMg} / \mathrm{Ca}$ & $0.20 \pm 0.03$ & $0.24 \pm 0.04$ & $0.21 \pm 0.03$ \\
& & & \\
\hline
\end{tabular}

$1219.5 \mathrm{~m}$. We have removed data from a few samples that were marked for possible contamination. These samples had higher values of both $\mathrm{Li}^{+}$and $\mathrm{K}^{+}$, which is a good indicator for contamination. The rest of the data from this series show no sign of contamination, and the measured $\mathrm{Li}^{+}$profile appears to be a real ice-core signal. Samples were measured in random order, which excludes the possibility that the $\mathrm{Li}^{+}$profile could be a systematic artefact from the measurements.

Four-metre averages of concentrations, and ratios between average concentrations from this data series are listed inTable 4. The last column in the table shows values from the deepest part of the section. In the $\delta^{18} \mathrm{O}$ profile this part represents the climate just prior to the cold event, and the evaluated data from this part of the core have values typical of data from the NorthGRIP Holocene section at 9-350 m depth. During the series, the $4 \mathrm{~m}$ average value of $\delta^{18} \mathrm{O}$ decreases about $1 \%$, and $\mathrm{Ca}^{2+}$ increases about $40 \%$. Alley and others (1997) report a decrease in $\delta^{18} \mathrm{O}$ of $2 \%$ and an increase in $\mathrm{Ca}^{2+}$ of $60 \%$ during the $8.2 \mathrm{kyr}$ BPevent in the GISP2 ice core.

\section{DISGUSSION}

\section{Holocene seasonals and glacial transition}

In the data series from the NorthGRIP Holocene seasonal

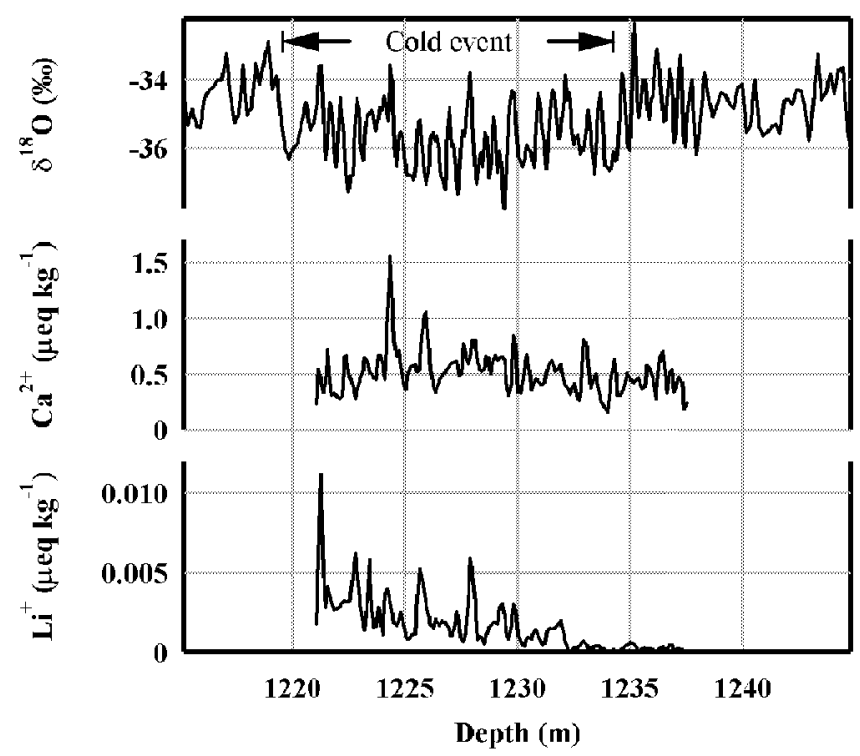

Fig. 4. $\delta^{18} \mathrm{O}, \mathrm{Ca}^{2+}$ and $\mathrm{Li}^{+}$profiles from the NorthGRIP ice core showing the Holocene $8.2 \mathrm{kyr} B P$ cold event. The $\mathrm{Ca}^{2+}$ and $\mathrm{Li}^{+}$sections represent approximately 170 years. In the deeper part of these sections the $\mathrm{Ca}^{2+}$ and $\mathrm{Li}^{+}$concentrations are similar to typical Holocene values.

series and the GRIP GS-21/GIS-20 transition series we see that the $\mathrm{Li}^{+}$profiles show the same pattern as $\mathrm{Na}^{+}$and/or $\mathrm{Ca}^{2+}$. We would expect this if the sources for $\mathrm{Li}^{+}$are sea salt and mineral dust. The ratios between the average measured values of $\mathrm{Li}^{+}$and $\mathrm{Na}^{+}$range between $0.0010 \pm 0.0003$ and $0.0013 \pm 0.0004$, which is 20 times higher than the $\mathrm{Li} / \mathrm{Na}$ ratio of $0.06 \times 10^{-3}$ in sea water. This means that sea salt can only contribute $5 \%$ of the $\mathrm{Li}^{+}$measured, as long as no significant ion fractionation occurs in sea-salt aerosols. Such a fractionation has not been observed in Greenland ice cores for other sea-salt components. We therefore suggest that the $\mathrm{Li}^{+}$measured in the Holocene seasonal series and the GS-21/GIS-20 transition series is mainly a dust-derived component.

If $\mathrm{Li}^{+}$originates from a mixture of different mineral types we expect to see varying ratios between $\mathrm{Li}^{+}, \mathrm{nss} \mathrm{Mg}^{2+}$ and $\mathrm{Ca}^{2+}$ concentrations as the composition of mineral types in the samples varies. In both series, the $\mathrm{Li} / \mathrm{Ca}$ ratio of individual samples varies and has a lower limit of 0.0002 . This lower limit of the $\mathrm{Li} / \mathrm{Ca}$ ratio fits well to the content of lithium in average marine carbonates (see Table 2). This supports the assumption that lithium in the Greenland ice cores is of terrestrial origin and has a potential application in the analysis of dust aerosols in Greenland ice cores.

Studies of insoluble dust particles in the GRIP ice core

Table 4. Average values of $\delta^{18} \mathrm{O}$, average concentrations in $\mu$ eq $\mathrm{kg}^{-1}$ of $\mathrm{Ca}^{2+}$ and $\mathrm{Li}^{+}$and ratios between average concentrations of various cations evaluated for $4 \mathrm{~m}$ sections from the NorthGRIP ice-core Holocene $8.2 \mathrm{kyr}$ BP cold event series

\begin{tabular}{|c|c|c|c|c|}
\hline Section & $1221-1225 \mathrm{~m}$ & $1225-1229 m$ & $1229-1233 m$ & $1233-1237.5 \mathrm{~m}$ \\
\hline$\delta^{18} \mathrm{O}(\% \mathrm{o})$ & -35.35 & -36.07 & -35.61 & -34.97 \\
\hline $\mathrm{Ca}^{2+}\left(\mu \mathrm{eq} \mathrm{kg}^{-1}\right)$ & $0.54 \pm 0.03$ & $0.61 \pm 0.03$ & $0.50 \pm 0.03$ & $0.43 \pm 0.02$ \\
\hline $\mathrm{Li}^{+}\left(\mu \mathrm{eq} \mathrm{kg}^{-1}\right)$ & $0.0033 \pm 0.0005$ & $0.0020 \pm 0.0002$ & $0.0011 \pm 0.0001$ & $0.0002 \pm 0.0001$ \\
\hline $\mathrm{Li} / \mathrm{Na}(\mathrm{eq} / \mathrm{eq})$ & $0.012 \pm 0.002$ & $0.0074 \pm 0.0001$ & $0.0040 \pm 0.0006$ & $0.0006 \pm 0.0001$ \\
\hline $\mathrm{Li} / \mathrm{Ca}$ & $0.006 \pm 0.001$ & $0.0033 \pm 0.0005$ & $0.0023 \pm 0.0003$ & $0.0005 \pm 0.0001$ \\
\hline $\mathrm{Na} / \mathrm{Ca}$ & $0.50 \pm 0.05$ & $0.45 \pm 0.05$ & $0.57 \pm 0.06$ & $0.78 \pm 0.08$ \\
\hline $\mathrm{Mg} / \mathrm{Ca}$ & $0.36 \pm 0.04$ & $0.34 \pm 0.03$ & $0.36 \pm 0.04$ & $0.41 \pm 0.04$ \\
\hline $\mathrm{nssMg} / \mathrm{Ca}$ & $0.26 \pm 0.04$ & $0.24 \pm 0.04$ & $0.23 \pm 0.04$ & $0.24 \pm 0.04$ \\
\hline
\end{tabular}


suggest that these particles originate in eastern and central China (e.g. Svensson and others, 2000), but the source of soluble calcium to the central Greenland ice cores and the relation to the insoluble dust are not completely understood. There is a difference in the calcium/dust ratio in different climatic periods (Steffensen, 1997). There is also a difference in the ratios between dust-derived ionic components in different climatic periods (De Angelis and others, 1997). Laj and others (1997) measured the insoluble part of the aerosols on filtered samples and the total content of elements in evaporated samples using microprobe techniques. They found that fractions of soluble $\mathrm{K}, \mathrm{Ca}, \mathrm{S}$ and $\mathrm{Fe}$ are different in different climatic periods and that the correlation between soluble and insoluble contents of these four elements is very poor. De Angelis and others (1997) and Laj and others (1997) suggest that a change in source contribution to mineral dust aerosols in Greenland ice cores occurs during climate changes.

\section{Holocene 8.2 kyr BP cold event}

The data from the NorthGRIP 8.2 kyr BP Holocene cold event show an increase in the $\mathrm{Li}^{+}$concentration of more than one order of magnitude. The $\mathrm{Li}^{+}$change seen in the series is not correlated to any other of the measured ions. The $\mathrm{Li}^{+}$profile from $9-350 \mathrm{~m}$ in the NorthGRIP ice core bears no resemblance to the $8.2 \mathrm{kyr}$ BP series. Therefore the data from the $8.2 \mathrm{kyr}$ BP event represent a special event with respect to lithium. We cannot say if the $\mathrm{Li}^{+}$change seen in the $8.2 \mathrm{kyr}$ BP data series is directly related to the cold event. The time delay of the increase of $\mathrm{Li}^{+}$concentrations relative to the decrease in $\delta^{18} \mathrm{O}$, and the missing decrease later during the cold period suggest that the pattern of $\mathrm{Li}^{+}$concentrations seen in the series is not directly linked to the temperature drop. However, since the $8.2 \mathrm{kyr} B P$ event is a special climate event, the increase in $\mathrm{Li}^{+}$could be indirectly related to some climate changes taking place during the event.

Some clay minerals have relative lithium and calcium contents that correspond to the high ratio of the measured concentrations of $\mathrm{Li}^{+}$and $\mathrm{Ca}^{2+}$ in the $8.2 \mathrm{kyr}$ BP series. But it is unlikely that such a high increase in the measured $\mathrm{Li}^{+}$ concentration, and no significant change in other dustderived components, is only an effect of a change in mineral composition due to changes in source contribution. We therefore need to find an additional source of $\mathrm{Li}^{+}$in this series, but we have no candidate for such a source. To understand the lithium chemistry of the $8.2 \mathrm{kyr}$ BP series, additional IC measurements to extend the data series would be helpful in order to clarify whether the concentration of soluble lithium increases further and for how long the lithium event lasts. Analysis of the insoluble fraction of components and of the mineralogy in this ice-core series would also be valuable in showing whether a change in mineral composition or a change in the soluble fraction of lithium has caused the increased $\mathrm{Li}^{+}$concentrations and what kind of changes in climate could explain such a change in lithium. Since the isotopic composition of lithium varies in material of different geological origin (e.g. Hoefs and Sywall, 1997), an analysis of the isotopic composition of lithium in this ice-core series might indicate whether the lithium is of volcanic origin or whether it comes from secondary minerals.

\section{GONGLUSION}

The main result of this work is the introduction of the $\mathrm{Li}^{+}$ion in ice-core analysis. We have shown that it is possible to measure a reliable lithium signal from ice cores in concentrations down to $0.0001 \mu \mathrm{eq} \mathrm{kg}^{-1}$ using IC with a reproducibility of $15 \%$ for concentrations close to the detection limit.

The data profiles of $\mathrm{Li}^{+}$from a NorthGRIP Holocene seasonal series and from the GRIP GS-21/GIS-20 transition series demonstrate that $\mathrm{Li}^{+}$data from ice cores have a potential application in the analysis and interpretation of ice-core dust chemistry. Future analysis of the ice-core chemistry of lithium may provide a better insight into the chemistry of the dust-derived ionic components and the relation between soluble calcium and dust in ice cores. The $\mathrm{Li}^{+} / \mathrm{Ca}^{2+}$ relation can contribute to a characterization of calcium sources and to an analysis of potential solubility effects on mineral dust particles. The $\mathrm{Li}^{+}$component might also give some new information about ice-core chemistry, as suggested by the independent behaviour of the $\mathrm{Li}^{+}$component to other species during the $8.2 \mathrm{kyr}$ BP Holocene cold event.

The NorthGRIP $8.2 \mathrm{kyr}$ cold-event series represents a special lithium event where the source of lithium to the icecore samples is unknown. Further IC measurements, along with analysis of the insoluble fraction and isotopic composition of lithium in this series, would provide information about the origin of the $\mathrm{Li}^{+}$measured in this series.

\section{ACKNOWLEDGEMENTS}

The GRIP project is organized by the European Science Foundation with eight nations (Belgium, Denmark, France, Germany, Iceland, Italy, Switzerland and the United Kingdom), and the European Economic Community. The NorthGRIP project is directed and organized by the Department of Geophysics at the Niels Bohr Institute for Astronomy, Physics and Geophysics, University of Copenhagen. It is supported by funding agencies in Denmark, Belgium, France, Germany, Iceland, Japan, Sweden, Switzerland and the United States of America. We thank GRIP and NorthGRIP participants and supporters for their cooperative effort. We also thank reviewers for useful comments.

\section{REFERENGES}

Alley, R. B., P. A. Mayewski, T. Sowers, M. Stuiver, K. C. Taylor and P. U. Clark. 1997. Holocene climatic instability: a prominent, widespread event 8200 yr ago. Geology, 25(6), 483-486.

Betti, M., G. Giovannoni, M. Onor and P. Papoff. 1991. Optimisation of the procedure for the determination of alkali and alkaline earth elements in sea water by suppressed ion chromatography. F. Chromatogr., 546(1-2), $259-271$.

Dahl-Jensen, D. and 8 others. 2002. The NorthGRIP deep drilling program. Ann. Glaciol., 35 (see paper in this volume).

Dansgaard, W. and 10 others. 1993. Evidence for general instability of past climate from a 250-kyr ice-core record. Nature, 364(6434), 218-220.

De Angelis, M., J.-P. Steffensen, M. Legrand, H. Clausen and C. Hammer 1997. Primary aerosol (sea salt and soil dust) deposited in Greenland ice during the last climatic cycle: comparison with East Antarctic records. 7. Geophys. Res., 102 (C12), 26,681-26,698.

Fuhrer, K., E. W. Wolff and S. J. Johnsen. 1999. Timescales for dust variability in the Greenland Ice Core Project (GRIP) ice core in the last 100,000 years. 7. Geophys. Res., 104(D24), 31,043-31,052.

Heier, K. S. and G. K. Billings. 1970. Lithium. In Wedepool, K. H., ed. Handbook of geochemistry. Berlin and Heidelberg, Springer Verlag, 3E1-3Ol.

Hoefs, J. and M. Sywall. 1997. Lithium isotope composition of Quaternary and Tertiary biogene carbonates and a global lithium balance. Geochim. Cosmochim. Acta, 61(13), 2679-2690.

Holland, H. D. 1984. The chemical evolution of the atmosphere and oceans. Princeton, NJ, Princeton University Press.

Hughes, L. S. and 8 others. 2000. Evolution of atmospheric particles along trajectories crossing the Los Angeles basin. Environ. Sci. Technol., 34(15), 
3058-3068.

Klitgaard-Kristensen, D., H. P. Sejrup, H. Haflidason, S. Johnsen and M. Spurk. 1998. A regional 8200 cal. yr BP cooling in northwest Europe, induced by final stages of the Laurentide ice-sheet deglaciation? f. Quat. Sci., 12(2), 165-169.

Laj, P. and 7 others. 1997. Distribution of $\mathrm{Ca}, \mathrm{Fe}, \mathrm{K}$, and $\mathrm{S}$ between soluble and insoluble material in the Greenland Ice Core Project ice core. $\mathcal{F}$. Geophys. Res., 102(C12), 26,615-26,623.

Lyons, W. B. and K. A. Welch. 1997. Lithium in waters of a polar desert. Geochim. Cosmochim. Acta, 61 (20), 4309-4319.

Mayewski, P. A. and 6 others. 1997. Major features and forcing of high-latitude Northern Hemisphere atmospheric circulation using a 110,000year-long glaciochemical series. 7. Geophys. Res., 102(C12), 26,345-26,366.

Silva, P. J., R. A. Carlin and K. A. Prather. 2000. Single particle analysis of suspended soil dust from southern California. Atmos. Environ., 34(11),
$1811-1820$.

Singh, R. P. and N. M. Abbas. 1996. Suppressed ion chromatographic determination of lithium, sodium, ammonium and potassium concentrations in sub-surface brines. 7. Chromatogr., Ser. A, 733, 93-99.

Steffensen, J. P. 1997. The size distribution of microparticles from selected segments of the GRIP ice core representing different climatic periods. 7. Geophys. Res., 102(C12), 26,755-26,763.

Svensson, A., P. E. Biscaye and F. E. Grousset. 2000. Characterization of late glacial continental dust in the Greenland Ice Core Project ice core. 7. Geophys. Res., 105(D4), 4637-4656.

Walker, M.J.C. and 7 others. 1999. Isotopic "events" in the GRIP ice core: a stratotype for the Late Pleistocene. Quat. Sci. Rev., 18, 1143-1150.

Wedepohl, K. H. 1995. The composition of the continental crust. Geochim. Cosmochim. Acta, 59(7), 1217-1232. 